\title{
FRAUDE CONTRA CREDORES: NOÇÃO DE FRAUDE EM GERAL. ESCORÇO HISTÓRICO E QUESTÕES SOBRE A FRAUDE CONTRA CREDORES. AÇÃO PAULIANA
}

FRAUD COMMITTED AGAINST CREDITORS: NOTION OF FRAUD IN GENERAL. HISTORICAL SUMMARY AND ISSUES ON FRAUD AGAINST CREDITORS. PAULIAN ACTION

\author{
José Luiz Gavião de Almeida* \\ Josias Jacintho Bittencourt ${ }^{* *}$
}

\begin{abstract}
Resumo:
Este artigo não tem o objetivo de trazer respostas definitivas, obviamente, para a fraude contra credores, tampouco realizar estudos aprofundados sobre o vocábulo fraude - nem no Direito brasileiro, nem no Direito Comparado. Também não há a intenção de estudar a hermenêutica, a interpretação e a exegese aplicáveis. Apesar disso, alguns conceitos de fraude serão analisados, tanto no âmbito primitivo como no âmbito contemporâneo do Direito. Nuances sobre o conceito e a problemática da fraude são importantes para pensar, repensar e compreender a sua inserção na frase técnico-jurídica fraude contra credores. Nuances sobre a expressão ação pauliana, contida no título deste artigo, também são importantes para compreender os objetivos do estudo. Marcus Tullius Cicero (106-43 a.C.) articulou um interessante conceito de direitos e deveres, no contexto da fraude: "Embora o erro possa ser feito de duas maneiras, isto é, pela força ou pela fraude, ambas são bestiais; a fraude parece pertencer à raposa astuta, enquanto a força pertence ao leão. Apesar de ambas serem totalmente indignas do homem, a fraude é a mais desprezível. Isso porque, de todas as formas de injustiça, nenhuma é mais flagrante que a do hipócrita que, no exato momento em que é falso, faz questão de parecer virtuoso". Este é o propósito, mesmo que singelo, deste artigo.

Palavras-chave: Direito Civil. Fraude primitiva. Fraude contra credores. Ação pauliana.
\end{abstract}

\begin{abstract}
:
This paper does not aim to bring definitive answers to fraud against creditors, nor does it carry out in-depth studies on the term fraud - neither in Brazilian Law nor in Comparative Law. There is also no intention to study the applicable hermeneutics, interpretation and exegesis. Despite this, some concepts of fraud will be analyzed, both in the primitive and contemporary scope of law. Nuances about the concept and its problems are important matters which must be thought and to the understanding of the sentence "fraud against creditors". The "Paulian Action", contained in the title of this article, is also important to understand the objectives of the study. Marcus
\end{abstract}

\footnotetext{
José Luiz Gavião de Almeida é Professor Titular de Direito Civil na Faculdade de Direito da Universidade de São Paulo (USP) e Desembargador do Tribunal de Justiça de São Paulo.

** Josias Jacintho Bittencourt é Professor de Direito. Fez Pós-Doutorado em Direito na Universidade de Coimbra, com estágio Docente por intermédio da CAPES-MEC, Brasil. É Doutor em Direito pela Pontifícia Universidade Católica de São Paulo (PUC-SP).
} 
Tullius Cicero (106-43 BC) articulated an interesting concept of rights and duties, in the context of fraud: "While wrong may be done, then, in either of two ways, that is, by force or by fraud, both are bestial: fraud seems to belong to the cunning fox, force to the lion; both are wholly unworthy of man, but fraud is the more contemptible. But of all forms of injustice, none is more flagrant than that of the hypocrite who, at the very moment when he is most false, makes it his business to appear virtuous".

Keywords: Civil Law. Primitive fraud. Fraud against creditors. Paulian action.

Introdução $^{1}$

Em 26 de junho de 2020 o Jornal da Universidade de São Paulo (USP) publicou que a Organização Meteorológica Mundial (OMM) anunciou que o relâmpago mais extenso do mundo ocorreu no Brasil, em 31 de outubro de 2018. Com cerca de 710 $\mathrm{km}$, o percurso do raio equivale a distância entre a Inglaterra e a Suíça. Raios longos são conhecidos como megaflashes.

As descobertas dos ofensivos relâmpagos megaflashes revelam a dimensão das preocupações de segurança pública, social e climática, tendo em vista que eles percorrem grandes distâncias através de nuvens eletrificadas. As consequências são extremamente graves.

Segundo a OMM, os extremos de um relâmpago são medições vivas do que a natureza é capaz, com informações científicas valiosas que estabelecem limites à escala dos raios. Portanto, os relâmpagos representam um grande risco à vida das pessoas, todos os dias, todos os meses, todos os anos.

Em um trocadilho relâmpago-fraude, qual é a dimensão e a extensão conceitual de fraude, no Brasil e no Direito Comparado? Assim como os relâmpagos, fraude provoca um dano "instantâneo", "momentâneo", "durável”, "infindável”, ou com "lonjura" e "longura"? Os relâmpagos-fraudes têm capacidade de percorrer pequenas ou imensas distâncias? Seriam megaflashes, independentemente das fronteiras geográficas?

As respostas para estas perguntas são complexas, a depender do Direito de cada país, mesmo com a internacionalização dos conceitos de Direito Privado e Direito Público. Apesar disso, inegável que fraude é, também, o resultado de estudos da epistemologia, axiologia, sociologia e dogmáticas jurídicas de um determinado percurso histórico-contemporâneo.

\footnotetext{
$\overline{1}$ Algumas citações são fruto de pesquisas feitas para a preparação de aulas. Elas ficaram gravadas na memória, às vezes com seus autores. Mas depois de muitos anos ficou difícil sua localização. Por isso são elas lembradas pelos seus autores, que merecem o crédito, embora sem indicação de fonte, conquanto, como disse o importante geógrafo brasileiro, Milton Santos, “antes que o nome seja adotado e repetido é muito melhor que as nossas ideias o sejam".
} 
Este artigo não tem o objetivo de trazer respostas para as questões anteriores, tampouco realizar estudos aprofundados sobre o vocábulo fraude - nem no Direito brasileiro, nem no Direito Comparado. Também não há a intenção de estudar a hermenêutica, a interpretação e a exegese aplicáveis. Apesar disso, as indagações realizadas e algumas nuances a respeito do conceito de fraude são importantes para pensar, repensar e compreender a sua inserção na frase fraude contra credores.

Nuances introdutórias sobre a expressão ação pauliana, contida no título deste artigo, também são importantes para compreender preliminarmente os objetivos do estudo. A palavra pauliana tem raízes semânticas no nome do jurisconsulto romano Paulus, do século II. Silva (1997, p. 56) escreve que a ação pauliana é um tipo de ação que os credores possuem para anularem os atos praticados pelo devedor, por meio dos quais, dolosa e intencionalmente, inclusive sob fraude, onerou ou alheou bens da sua propriedade; bens únicos que poderiam ser usados para liquidar dívidas.

A fraude contra credores e a ação pauliana, também conhecida como ação revogatória ou revocatória, estão regulamentadas nos arts. 158 a 165 do Código Civil de 2002. Parte destes artigos são objeto de análise neste texto, além de outras normas eventualmente aplicáveis, especialmente do Direito Civil e do Direito Processual.

\section{Fraude na história primitiva}

O Direito não se inventa; o que hoje vigora, abrolhou de germes existentes no passado. O Direito é, portanto, um produto lento que vai se adaptando ao meio no percurso do seu processo transformador. Só pessoas estranhas à ciência jurídica acreditam na possibilidade de se fazerem leis inteiramente novas. $\mathrm{O}$ autor da norma positiva apenas assimila, aproveita e consolida o que encontra na sociedade e, em pequena parte, entre povos do mesmo grau de civilização. O agente legislador é apenas um aparente autor, um produtor das formalidades de uma norma que, nos tempos primitivos, era predominantemente "formalizada" nos costumes. Portanto, escreve Santos (2000, p. 6-147), o Direito atual consiste em reproduções, ora integrais, ora ligeiramente modificadas, de preceitos preexistentes. Inclusive na fraude e com fraude. Talvez por isso que Goethe escreveu em sua obra prima, Fausto: "Deixa de jactância, oh original! Como te mortificarias em saber que não há nada, estúpido ou sagaz, que já não tenha sido pensado antes!".

O indivíduo que legisla é mais ator que autor; traduz apenas o pensar e o sentir alheios. Outras vezes, quase sempre, utiliza meios inadequados de expressão, induzindo o intérprete a erros. As razões de tantos paradoxos estão naquilo que os impele, como as forças subterrâneas, irresistíveis, que são mais profundas que os antagonismos 
que envolvem os interesses pessoais; antagonismos particulares em detrimento dos interesses coletivos.

Gonzales (2005, p. 86) entende que o idealismo jurídico prepara a lei e o Direito, mas não necessariamente decorrentes da realidade ou das necessidades sociais. Isso porque, ao legislador, o que importa é o conceito ideal de lei e de Direito, ao qual a realidade fática deverá adaptar-se. $\mathrm{O}$ sistema jurídico idealista enquadra a realidade fática à lei. Esta precede aos fatos concretos. Os homens e a vida social, assim como os atos e fatos sociais e políticos, devem adaptar-se à ordem social ideal. Dizer que o legislador cria uma lei ideal, significa dizer que a lei prevê uma conduta ideal dos cidadãos na vida em sociedade.

Nesse contexto, onde, quando, quem e como iniciou a fraude? Algumas nuances histórico-primitivas sobre fraude são importantes para este artigo, porque, segundo Cícero, em De Oratore, II, publicado em 55 a.C., "a história é testemunha do passado, luz da verdade, vida da memória, mestra da vida, e anunciadora dos tempos antigos". Conceito que se aplica, também, para o vocábulo fraude, tanto no sentido amplo como no sentido estrito.

No contexto religioso, teólogos defendem que a fraude começou no Éden, com Adão e Eva, ou seja, através da proposta fraudulenta que o diabo fez a Eva para comer o fruto proibido por Deus. Se comesse, conforme escrito em Gênesis, Eva conheceria todo o "bem e o mal" da terra, igualando-se ao próprio Criador.

Historiadores, como o catedrático da Universitá di Roma, Ambrogio Donini (1965, p. 76-101), escreve que a fraude ganhou importante dimensão no Egito antigo. Nos anos 3300 a.C., por exemplo, grandes monumentos tornaram a história do Egito famosa por causa da política, da ciência, das "tecnologias", da organização do trabalho e da direção da sociedade que, provavelmente, exigiu longos séculos de elaboração. Assim como os necessários "trabalhadores manuais", havia ao redor dos edifícios importantes "trabalhadores intelectuais", como astrônomos, matemáticos, economistas, arquitetos, contadores, coletores, escribas, juízes e sacerdotes que, diante das novas exigências da sociedade, forneciam ao faraó preciosas soluções para a direção do Estado. Portanto, um ambiente propício para realizar fraudes.

Vitoriosos, vencidos ou superados na prática da vida cotidiana, os costumes e os ritos perpetuavam-se através da religião, da política e, certamente, através de métodos aperfeiçoados e dos novos sistemas criados.

Como supremacia e fonte de toda a sabedoria e conhecimento, as divindades do panteão egípcio eram representadas na forma de animais, que acompanhavam os faraós e as pessoas importantes tanto em vida como após a morte. Por exemplo, o falcão (Horo), o carneiro (Khmem), o boi (Hap, Ápis em Mênfis), o touro (Aton), a vaca (Hathor), o aríete (Âmom, em Tebas; Harsafiet, em Eracleópolis; Osíris, em Mendes no delta do Nilo), o 
chacal (Anúbis, que os romanos confundiram com um cão), o abutre (Nekhebt), o gato (Bast), o crocodilo (Sebek), a serpente (Set), o leão, o escorpião, a mosca, etc. Portanto, a fauna do país: animais domésticos e ferozes, répteis e aves de rapina. Esta cultura muito impressionou os gregos, já num período da sua história em que o culto dos animais tinha perdido toda significação.

E o que têm a ver os tais animais, aves e répteis sagrados - que permeavam a cultura do antigo Egito - com a ideia e o conceito de fraude? Segundo Parodi (2008, p. 1-4), é porque havia naquele contexto muitas pessoas que fraudavam ricos e nobres, vendendo falsos gatos e outros animais sagrados embalsamados para as suas cerimônias fúnebres. As "múmias" fraudulentas dos animais continham, na realidade, somente gravetos e algodão. Em muitos casos continham também pedaços de ossos de outros animais.

Portanto, desde a economia primitiva existem larápios provocando golpes no mundo dos negócios, ou seja, golpistas que se dedicam a pôr em prática várias formas de armadilhas, fraudes, esquemas e sistemas para enganar e roubar o próximo.

O Direito Material e o Direito Processual, por óbvio, precisam caminhar juntos diante dos conflitos de interesse, da lide, da fraude. Mas enquanto o Direito Material tem a função de preservar direitos, estabelecer deveres e inibir conflitos, o Direito Processual é o instrumento que tem como função servir o Direito Material e, ambos, solucionar litígios, como a fraude. Portanto, a eficácia e a efetividade dos “dois” Direitos alcançam os ideais da Justiça somente quando ambos compartilham e se interagem mutuamente.

Assim, o Direito é, nos sentidos amplo e restrito, uno, único, e nunca foi e nem pode ser fracionado, a não ser na pedagogia acadêmica para estudos. Portanto, impossível dissociar Direito Material de Direito Processual, mesmo no Direito Primitivo, em relação à fraude.

O Código de Hammurabi, redigido provavelmente entre 1810-1750 a.C., é, sem dúvida, o mais completo e melhor conjunto de leis do mundo antigo. Bouzon (2000, p. 15-153), no seu clássico livro $O$ Código de Hammurabi, faz importantes considerações sobre o Código e a primitiva sociedade da Mesopotâmia.

Inscrito numa pedra de diorito negro, com 2,25 $\mathrm{m}$ de altura, o Código foi descoberto na acrópole da capital elamita, Susa, atual Irã, em 1901. Com cerca de 282 artigos, o Código tratava de assuntos diversos, prescrevia direitos e deveres e tratava de fraudes e respectivas punições.

No art. $5^{\circ}$ do Código de Hammurabi havia importantes destaques processuais relacionados com a fraude. No caso, vinculados ao juiz da causa. O artigo tratava, por exemplo, das condutas fraudulentas, desvios de ética, negligência, imperícia e suborno. A pena era a de destituição permanente do cargo de juiz. Obviamente que todas 
as condutas prejudicavam o resultado do Processo, por envolver sentenças fraudulentas que mascaravam os ideais de Justiça.

Assim o art. $5^{\circ}$ :

Se um juiz fez um julgamento, tomou uma decisão, fez exarar um documento selado e depois alterou o seu julgamento, comprovarão contra esse juiz a alteração do julgamento que fez; ele pagará, então, doze vezes a quantia reclamada nesse processo e, na assembleia, fá-lo-ão levantar-se de seu trono de juiz. Ele não voltará a sentar-se com os juízes em um processo.

Portanto, "violar o documento selado com a sentença para alterar o resultado do julgamento" implicava em uma pena de "doze vezes a quantia reclamada", e "fá-lo-ão levantar-se de seu trono de juiz".

$\mathrm{O}$ art. 229 estabelecia outra possibilidade de fraude, através do betume para construção de moradia: "Se um pedreiro edifica uma casa para um awilum [homem livre, com todos os direitos], mas não reforça a estrutura da casa que construiu, e ela cai e causa a morte do dono da casa, o pedreiro será morto".

Para compreender a dinâmica e extensão deste artigo, importante recordar que as casas na Mesopotâmia, durante o período babilônico antigo, eram construídas, geralmente, com tijolos secos ao sol. A argamassa era o betume, que existia abundantemente na região. Portanto, as construções eram naturalmente frágeis. A qualidade da terra, a fraude no barro, a falta de cuidado ou de perícia do construtor podiam ser fatais. A obra, certamente, ruiria pouco tempo depois de habitada.

Na Bíblia, diversos textos estão relacionados com a fraude, tanto no Antigo Testamento como no Novo Testamento; tanto nos tempos "bíblico-primitivos" como nos tempos "bíblico-contemporâneos".

Nos tempos bíblico-primitivos a fraude possuía grande espaço nos negócios, nas compras e vendas de mercadorias, produtos, bens móveis e imóveis, pesos e medidas, etc. Naquele passado, as sentenças de personagens como Moisés, Davi, Salomão, Isaías, Amós e Miquéias, entre outros, demonstram que a preocupação com a fraude já era eminente.

Segundo a Torá, Moisés (Lv. 6.1-7) recebeu uma orientação divina para julgar processos desonestos, fraudulentos:

Se alguém enganar o seu próximo com respeito a algo que lhe foi confiado ou que lhe foi deixado como garantia, ou se roubar ou defraudar..., ou achar algum bem perdido e mentir a respeito disso, e se jurar falsamente a respeito de qualquer coisa... isto é o que deve fazer: devolver o que roubou, o que extorquiu, o que tomou por meio de fraude, o que foi confiado aos seus cuidados, a coisa perdida que achou... 
Gower (2002, p. 146-183) escreve que originalmente as tendas eram feitas de peles que, em muitas situações, eram substituídas por pelos de cabra, ovelhas (Êx. 25.4). Tendeiro era o status profissional de quem trabalhava com couro, tarefa que continuou nos séculos seguintes com técnicas aperfeiçoadas, ampliando habilidades. Prosseguiu em fábricas de recipientes, cintos e equipamentos militares, como capacetes, escudos e fundas de couro.

Além de tirar a pele do animal e remover o pelo, aplicando cal, o tendeiro precisava torná-la macia e, geralmente, tingi-la. As peles eram então mergulhadas em água contendo cascas de carvalho e folhas de sumagre, esfregados com estrume de cachorro. Eram "moldadas" à marteladas.

O trabalho era tão malcheiroso que o curtidor precisava trabalhar fora da cidade, na direção do vento predominante. Por ser tão desagradável, podia tornar-se causa de divórcio. Quando os servos de Cornélio foram procurar a casa de Simão, o curtidor, em Jope, não devem ter tido dificuldade em achá-la.

Os processos de tingimento do couro também estavam sujeitos à fraude. A cor vermelha (Êx. 25.4) era obtida de ovos de insetos, tipo cochonilhas. A cor azul-escuro (índigo) era obtida de casca da romã em conjunto com frutas tipo mirtilo, e o azul "mais claro" com aditivos de murex. O corante púrpura era preparado com o molusco murex (Êx. 25.3-7; At. 16.14). As cascas eram esmagadas, cozidas em sal e deixadas ao sol para que a secreção tornasse numa cor azul-celeste, vermelho púrpura, entre outras (Nm. 15.38; Et. 8.15). No Egito, o amarelo era feito com o açafrão, e os romanos extraíam das flores da açafroeira.

Os corantes das cores eram fabricados com uma solução de água e aditivos de potassa e cal. Os pigmentos eram acrescentados após alguns dias, e o tingimento era feito em vasilhas de cerâmica ou bacias de pedra. No contexto, a fraude ocorria através da "péssima" qualidade da mão de obra e dos materiais aplicados que, com aparente beleza, eram desbotados diante do excesso de claridade e da chuva.

No âmbito da Ordem Econômica, a fraude também ocupava espaço do Direito Econômico, do Direito Penal Econômico, etc. Tudo em face da cultura, dos costumes, da linguagem e dos pessoais interesses do intérprete.

Grau (2008, p. 67) escreve que, apesar da obviedade de distinções entre passado e presente, a generalidade de pensamento das pessoas pode se enredar na ambiguidade de expressão, de conceitos, fato que se multiplica, por exemplo, quando o conceito moderno de ordem econômica constitucional é estendido para aqueles tempos primitivos. E isso, tanto quando o leitor não pratica nenhum exercício de reflexão, soçobrando então na inconsequência a que o reduz sua incapacidade de raciocinar, quando, embora o faça, não seja capaz de romper o mistério da ordem econômica. É esse 
mistério, de resto, responsável pelo fascínio que a expressão de ideias e ideais - tão só a expressão - exerce sobre tantas pessoas.

Este conceito também é aplicável, de forma direta ou indireta, à fraude primitiva e suas respectivas variantes, considerando o seu aspecto também econômico.

No livro de Salmos (101.7) Davi escreveu uma advertência para quem pratica fraude: "O que usa de fraude não habitará em minha casa; o que profere mentiras não estará firme perante os meus olhos".

Salomão, no seu livro de Provérbios (20.17), ironicamente previu o destino dos desonestos, dos praticantes de fraudes: "Suave é ao homem o pão ganho por fraude, mas, depois, a sua boca se encherá de pedrinhas de areia".

Isaías (5.8-12) discursou contra fraudes por causa de ganâncias: "Ai dos que ajuntam casas e mais casas, dos que acrescentam um campo a outro, até que não haja mais onde alguém possa erguer sua casa, tornando-se os moradores absolutos da terra!".

Amós (6.1-7) advertiu os poderosos que exploravam os necessitados, com as inevitáveis consequências:

Ai dos que dormem em camas de marfim, e se espreguiçam confortavelmente sobre seus belos leitos, e comem os melhores cordeiros do rebanho, e os novilhos mais gordos; que cantam ao som da viola, e inventam para si instrumentos musicais... Que bebem vinho em taças, e se ungem com o mais excelente óleo, mas não se afligem pela ruína de José. Por essa razão estareis entre os primeiros a serem presos e expatriados; então cessarão os banquetes dos que vivem folgadamente.

Miquéias (2.1-4) condenou os fraudadores profissionais:

Ai daqueles que tramam maldades; que mesmo repousando em suas casas planejam crueldades. E, logo que o dia amanhece, executam seus planos malignos, pois têm poder para isso. Eles cobiçam campos e terrenos, e tomam posse deles; invejam e desejam casas e propriedades de outros e acabam por apoderarem-se delas. E não têm escrúpulos em agir com violência contra qualquer homem e sua família; agridem com impiedade o semelhante e os seus herdeiros.

Segundo a Bíblia King James, tradução da versão original de 1611 (2016, p. 1.669), o contexto do discurso de Miquéias envolveu combate às fraudes, à extorsão de bens, de terras e opressão aos pobres. Por isso, levantou a voz contra uma cultura de malignidade que havia se apoderado na psique de ricos e poderosos que negavam direitos cívicos aos mais fracos e necessitados. Eram negociantes, fraudadores, que exploravam os pobres, trabalhadores, violando a consciência e o espírito da Torá, da Lei. 
O problema daqueles negócios é que os capitalistas queriam ter cada vez mais riquezas, enquanto os explorados ficavam cada vez mais pobres. Tudo indica que as trapaças aconteciam tanto em nível individual e coletivo como no âmbito local e "nacional". O percurso histórico da fraude possui, portanto, alcance e interpretação variáveis; jamais inexistentes!

\section{Escorço conceitual da fraude}

Page, no seu clássico livro Traité de Droit Civil Belge (1942, p. 806), também citado por Gilissen (2001, p. 13, 31-50), escreve que a História do Direito é muitas vezes tratada com um condescendente desdém, sendo o Direito totalmente prejudicado por aqueles que entendem ser melhor ocupar-se exclusivamente com o Direito Positivo. Os juristas que se interessam pela História do Direito, quase sempre à custa de investigações muito longas e muito laboriosas, são frequentemente acusados de pedantismo... Uma apreciação deste gênero não beneficia o Direito e nem aqueles que desprezam a sua História. Quanto mais avançamos no Direito Civil, mais constatamos que a História do Direito, muito mais que a Lógica ou a Teoria, é a única capaz de explicar o que as nossas instituições são e porque é que são desde que existem.

O Direito da República, na Grécia dos anos 800-500 a.C. e, depois, do Império Romano, são provenientes de uma evolução milenária do Direito na bacia do Mediterrâneo. Ao Direito Grego, às cidades gregas, sobretudo Atenas, deve-se muito o alto grau de desenvolvimento cultural, político e jurídico contemporâneos, escreve Gilissen. Historiadores e filósofos analisaram as instituições daquele tempo, e a partir de conceitos greco-romanos elaboraram sistemas teóricos de governo ideal, dando origem à ciência política. Entretanto, os gregos antigos foram herdeiros de outras civilizações ainda mais antigas, que haviam se desenvolvido no Império do Egito e na Ásia Menor. Mas em todas essas épocas existiram, de forma direta ou indireta, sistemas de combate à fraude.

Com raras exceções, os pesquisadores partem da Dogmática do Direito Romano para conceituar e "definir" os paradigmas e a plenitude do percurso histórico do Direito. Grande erro! Esquecem que, "antes” da Dogmática, do Direito Posto, do Direito Positivo, são necessárias pesquisas e estudos de Epistemologia, Axiologia e Sociologia jurídicas. Quando estas áreas são desprezadas, com privilégio e exaltação única da Dogmática, os ideais de Justiça tornam-se comprometidos. É por isso que Tércio Sampaio Ferraz Júnior escreve que "o saber jurídico é mais amplo que um estrito saber dogmático".

Inexplicável é o fato, dessarte, quando legisladores e governantes ímprobos adotam facções e suas respectivas ideias, misteriosamente juntos, combinando mudanças de projetos de efetividade da Justiça por novos projetos de reformas; há, então, uma prática de injustiças. Tudo sorrateiramente sustentadas por adversários "antigos" que torna-me 
dominadores na véspera! O grupo dominante aceita pacificamente as propostas, realizando o programa dos contrários e, não raro, até as inovações que combatera. Como resultado em todas as esferas e dimensões políticas, inclusive nas religiosas - o Direito pressuposto, positivado, torna-se refém dos intérpretes contaminados por crenças, ideologias e teorias fundamentalistas. Santos (2000, p. 6-147) escreve que o percurso de poder executivo e poder legislativo existe desde os tempos primitivos, com dimensões maiores ou menores a depender dos colegiados político-religiosos.

No Brasil, os constantes projetos legislativos para combate à corrupção, às fraudes, demonstram essa realidade factual. Mas é possível fazer coisas com palavras. Por isso, fazer normas e interpretar um texto significa explicar por que as palavras podem fazer várias coisas - e não outras - através do modo pelo qual são interpretadas, escreve Eco (2001, p. 27-51). Por isso a importância de ação, juntos num conjunto, dos membros do legislativo, executivo e judiciário. Todos com limites na interpretação.

No processo da linguagem, da interpretação, o importante é descobrir cientificamente a natureza da coisa para, no resultado prático visado pelo legislador, encontrar o critério que realmente vai conduzir à classificação do fenômeno no local que lhe corresponde. Evidentemente, não pode haver desprezo da epistemologia, da axiologia e da sociologia jurídicas para compreender a eficácia da dogmática e a sua efetividade.

Durante o processo, a opinião do legislador é despida de maior significado porque, tendo em vista que a figura jurídica já foi concebida, não lhe é dado alterar ou ignorar a natureza da coisa dentro do mundo do Direito onde ela se insere. O legislador não tem compromisso científico com o Direito. O jurista que interpreta e aplica a norma do legislador, ao contrário, tem sempre de agir cientificamente, a fim de encontrar e definir o efeito concreto do texto legislado. Assim entende Theodoro Júnior (2002, p. 59).

O intérprete da lei, por isso, não pode, de maneira alguma, ser um mero repetidor das palavras do legislador. Conceito aplicável, com veemência, ao jurista. Eco (2001, p. 27-51) escreve que o cientista precisa dispor de método próprio para desvendar o sentido e o alcance da norma, sem se escravizar à literalidade do texto legal. Entretanto, fundamental e necessário ter em mente que, entre a intenção do autor, do legislador e o propósito do intérprete, existe a intenção do texto.

Dinamarco (1980, p. 188-199) entende que um dos grandes problemas do Direito está na linguagem utilizada para expressar o pensamento do legislador. O grau de desenvolvimento de uma ciência pode ser conhecido pelo maior ou menor grau através do refinamento do seu vocabulário. Se os conceitos são mal definidos, se os fenômenos são confusos e insatisfatoriamente isolados, e se o método não é esclarecedor para estudiosos de determinada ciência, é natural que o texto será pobre devido a conexão sem precisão técnica entre palavras e linguagem. 
No caso do Direito, na medida em que a ciência jurídica se aperfeiçoa o vocabulário do jurista também vai sentindo os reflexos da evolução, tornando-se mais minucioso e apurado. Por isso que a linguagem do jurista de hoje não é a mesma do seu antecessor; e a ciência jurídica já se encontra profundamente modificada. Mas um linguajar contemporâneo não significa, necessariamente, que o linguajar seja melhor que o antigo. Isso porque os vocábulos e as expressões mudam, surgem e desaparecem, e na mesma proporção as pessoas que criam textos e normas.

A linguagem é, portanto, expressão de uma cultura, servindo não só para medir o grau de civilização que através dela se manifesta, mas também para chegar-se ao conhecimento das peculiaridades de uma sociedade organizada.

Apesar de a fraude possuir prismas conceituais, eles não têm significados contraditórios; possuem tão somente ênfases e dimensões específicas. É o caso, por exemplo, da fraude contra credores. Assim, estudar o percurso dos seus conceitos, especialmente nos âmbitos etimológico e jusfilosófico, é muito importante para compreender o seu dano na sociedade.

Segundo Silva (1997, p. 324), a palavra fraudar tem origem no latim fraudare. Em um conceito amplo, genérico, significa "usar de fraude". Exprime toda a ação de falsear ou ocultar a verdade com a intenção de prejudicar ou de enganar. $\mathrm{Na}$ técnica fiscal possui o sentido de falsificar ou adulterar, ou seja, "usar de ardil" para fugir ao pagamento de uma tributação: fraudar o fisco. Portanto, sonegar.

Fraudar também significa burlar. Neste sentido, também a ideia de fraudar $a$ lei, ou seja, de fugir ardilosamente à sua regra ou ao dever que nela se contém.

Formados ou derivados de fraudar há vocábulos como fraude, fraudulento, fraudatório e fraudador, entre outros. Fraude é o engano malicioso, fraudulento é onde há fraude em tudo, fraudatório é aquele que tem por objetivo a fraude, e fraudador é quem pratica fraude. Interessante, portanto, pensar e repensar em fraude à Lei, fraude constitucional, fraude civil, fraude penal, fraude processual, fraude de origem, fraude sexual, fraude fiscal, fraude contra credores, e fraude à execução, entre outras.

Segundo Cretella Júnior (2000, p. 316-317), o conceito de fraus (fraude) no Direito Romano possui alguns significados. Por exemplo, em um sentido pode significar "manobras fraudulentas"; em outro sentido, "dolo". Em dimensão técnica, a fraus pode envolver desde a falta cometida pelo liberto contra os direitos sucessórios do patrão até a fraus creditorium, ou seja, a fraude cometida por um vendedor insolvente em detrimento dos credores.

Assim, continua escrevendo, a fraus creditorium (fraude contra credores) é a manobra voluntária executada pelo devedor para tornar-se insolvente ou agravar seu estado de insolvência. É uma ação para diminuir ou malbaratar totalmente o patrimônio do devedor, tornando os credores prejudicados por falta de garantia. No antigo Direito 
a execução recaía, primeiro, sobre a própria pessoa do devedor, que respondia com o corpo as dívidas contraídas; depois, a execução deixa de ser pessoal para ser real. Os bens garantem os direitos do credor. Nesta segunda fase, o devedor procura prejudicar os credores, desviando os bens de que dispõe, libertando escravos, pagando suas próprias dívidas.

Lima (1965, p. 13-23) escreve que a partir do momento em que a manus injectio, ou seja, a execução pessoal, do corpo, passou para o patrimônio, para os bens do devedor, as legislações modernas tornaram-se "atualizadas". O princípio de que o patrimônio do devedor passa a ser garantia para o credor tornou-se comum e aceito pelo Direito.

Sob o prisma das atuais dimensões jusfilosófica e técnica, pode-se afirmar que a fraude continuou "ganhando novas roupagens" nos tempos do Novo Testamento, ou seja, fraudes tributárias, fraude fiscal, fraudes contra credores.

Alguns exemplos estão em histórias, discursos e advertências de Mateus, Lucas e Paulo.

A dinâmica das fraudes envolvia, obviamente, pessoas, dinheiro, moedas, como o talento, que era uma "grande" quantidade de dinheiro, e não uma única moeda. Certa ocasião Jesus contou a "Parábola dos Talentos", descrevendo realidades financeiras e fraudulentas locais (Mt. 25.14-30). Numa cultura rudimentar, a possibilidade de falsificar pesos e moedas era enorme, mas, ao mesmo tempo, eram úteis nas trapaças dos negociantes - consumidor e produtor. Usavam pesos para vender "gato por lebre" e, assim, realizar negócios ilícitos.

Gower (2002, p. 146-183) escreve que as pessoas que trabalhavam com dinheiro tinham muitas oportunidades de emprego, principalmente na cobrança de impostos. Muitos cambistas, com a cultura de praticar fraudes, eram chamados quando havia necessidade de moedas específicas; cobravam dez por cento pela troca.

Nos anos iniciais do Novo Testamento o comércio era um estilo de vida, e a Pax Romana (28 a.C. - 180 d.C.) ampliou a possibilidade de comércio por causa das viagens mais seguras. Roma passou a ser o centro da riqueza e do comércio, e "todas as estradas levavam a Roma". Naquele período, grandes quantidades de óleo de oliva foram importadas da Judeia, enquanto vinhos, vidros, maçãs, linho e algodão gregos tornaram-se comuns no Império Romano. Sem nenhuma isenção de tributos, havia total obrigação de pagamento dos tributos "alfandegários" ao Império Romano. Junto a toda essa dinâmica comercial e tributária, havia fraudes tanto na qualidade dos produtos comerciáveis e comercializados quanto nos impostos.

Os oficiais romanos normalmente "vendiam" algumas áreas alfandegárias, cidades de grandes negócios, a quem pagasse melhor o direito de explorar, de cobrar 
tributos para o Império. Os publicanos, por exemplo, eram grandes "colaboradores" da estratégia de exploração tributária, sendo, inclusive, "empregadores" de outras pessoas da comunidade. O cobrador-chefe administrava a coleta dos impostos, cobrava valores em excesso para ter lucros fraudulentos e o restante, conforme regra do "Código Tributário", era entregue ao Império.

Segundo Lucas $(19.2,8)$, o publicano Zaqueu era um famoso coletor de impostos em Jericó, que se tornou muito rico por causa de trapaças com os pobres e coleta fraudulenta de impostos; apesar de interpretações contrárias. No status de cobrador-chefe, admitiu possibilidades de fraude e prometeu a Jesus devolver quatro vezes o que recebera ilegalmente: "Senhor, darei metade das minhas riquezas aos pobres. E, se explorei alguém na cobrança de impostos, devolverei quatro vezes mais". Nesse contexto, os Judeus odiavam os publicanos, não só porque extorquiam dinheiro, praticavam fraude, mas também por serem considerados traidores e aliados do poder de ocupação.

No livro de Atos (13.10), o jusfilósofo Paulo pergunta aos fraudadores: "Ó homem cheio de todo tipo de fraude e maldade... inimigo de tudo o que é justo, você não vai parar de distorcer os caminhos retos do Senhor?".

Além das fraudes nos tempos bíblicos, as mitologias da antiga Grécia contemplam a realidade factual da fraude na mesma geografia do Império Romano.

Segundo Parodi (2008, p. 1-4), é interessante relembrar que, dentre outros deuses, as mitologias greco-romanas tinham o deus Hermes, que cuidava e protegia os ladrões e fraudadores, aplicando vários golpes nos demais deuses. Por isso, tinha frequentes problemas com Zeus, o chefe. Entre os nórdicos Europeus, Loki seria um deus que fazia todo tipo de trapaça e enganação, enlouquecendo os demais deuses. Parodi também menciona outras mitologias em que deuses fariam ações trapaceiras, como Anansi e sua lenda, na África; Akba-Atatdia, Manabozho e Ictinike, nas Américas; Bamapana, na Áustrália; Li-nezha e SunWukong, na China; Lemminkäinen, na Finlândia; Indra, na Índia; e Tracoloti, nos Maya, entre outros.

É por causa dos contextos mencionados, primitivos e antigos, com mitologias, ditos e lendas populares "por todo lado", que a fraude possui conexão direta e indireta com a vida cotidiana da História Antiga e na História Contemporânea. Com estas breves nuances de fraude no âmbito cultural e sociológico da humanidade, os tópicos seguintes tratam da fraude numa dimensão jusfilosófica, técnico-jurídica.

3. Hipóteses legais de fraude contra credores

O Código Civil de 2002 trata dos Fatos Jurídicos no Livro III da Parte Geral, que está subdividido em três Títulos. O primeiro Título está relacionado com Negócio Jurídico, que aborda temas como os Defeitos do Negócio Jurídico (arts. 138 a 
165) e a Fraude Contra Credores (arts. 158 a 165). O Título seguinte regulamenta os Atos Jurídicos Lícitos (art. 185); e o último Título normatiza os Atos Ilícitos (arts. 186 a 188).

No Código Civil de 1916 os Fatos Jurídicos também foram tratados no Livro III da Parte Geral, mas subdivididos em dois Títulos. O primeiro Título regulou no seu capítulo II os Atos Jurídicos, que tratou dos Defeitos dos Atos Jurídicos (arts. 86 a 113) e da Fraude Contra Credores (arts. 106 a 113). O capítulo III tratou das Modalidades dos Atos Jurídicos (arts. 114 a 128), enquanto o capítulo IV abordou a Forma dos Atos Jurídicos e a sua Prova (arts. 129 a 144). O Título II tratou dos Atos Ilícitos (arts. 159 e 160).

Apesar das expressões "Fatos Jurídicos", "Negócios Jurídicos”, "Defeitos dos Negócios Jurídicos", "Fraude Contra Credores", "Atos Jurídicos Lícitos" e "Atos Ilícitos" conterem evidente conexão entre si, este artigo tem o propósito de debater o conceito da eficácia e da efetividade da Fraude Contra Credores, sem desprezo das eventuais nuances sobre as outras expressões mencionadas.

É o caso das “conexões” entre os institutos. Segundo Theodoro Júnior (2002, p. 51), o Código Civil de 2002 trouxe para o Direito acertos e equívocos de "contexto": a) evoluiu grandemente no campo de defeitos dos negócios jurídicos inserindo no Direito Positivo novas e relevantes figuras como a lesão (art. 157) e o estado de perigo (art. 156). Atendeu, dessa forma, a notórios anseios sociais; b) também com inegável acerto deslocou a simulação do campo das anulabilidades para o das nulidades (art. 167); c) mas cometeu um desserviço ao Direito Civil brasileiro ao manter a fraude contra credores dentre as causas de anulabilidade do negócio jurídico (arts. 158 a 165), já que os rumos traçados pelo Direito Comparado contemporâneo, e a lição da doutrina nacional desde há muito tempo, catalogam a impugnação pauliana no âmbito da ineficácia, e não da invalidade.

Além de atribuir efeitos impróprios à natureza dos negócios viciados, escreve Theodoro Júnior, o Código Civil de 2002 reúne fenômenos heterogêneos sob a denominação única de "defeitos do negócio jurídico". Na verdade, nada há em comum entre os vícios de consentimento (ou de vontade) - erro, dolo, coação etc. - e os vícios funcionais (ou sociais), como a fraude contra credores.

Primitivamente, segundo Monteiro (1991, p. 215), o devedor respondia com o próprio corpo pelas obrigações assumidas. Estava ele então sujeito a duríssima execução corporal, por intermédio da manus injectio. A situação do devedor impontual era análoga à do escravo, exposto à vingança do credor sobre a própria pessoa, em detrimento da sua liberdade e até da vida. Com a promulgação da famosa Lei romana Lex PoeteliaPapiria (326 a.C.), o nexum foi abolido.

A Lex, com evolução conceitual sobre fraude, determinou uma "troca" nos processos de execução, ou seja, a extinção da dívida não podia ocorrer, como antes, por meio do corpo do devedor, mas do seu patrimônio. Inspirada em altos sentimentos 
humanitários, Tito Lívio escreveu que a Lex regulou os processos de execução da fraude por ser "a aurora de uma nova era de liberdade". A partir daquela época, até os dias atuais, as dívidas contraídas pelo devedor recaem sobre os seus bens. "É o princípio que ora anima o Direito universal", escreve.

No Brasil, a execução de dívidas civis com prisão é possível somente em casos excepcionais e restritos. Está prevista no art. 5\%, inciso LXVII, da Constituição Federal de 1988.

O novo tratamento da matéria pelo Código Civil de 2002, que não repetiu o conceito de ato jurídico do art. 81 do Código Civil de 1916, permite estabelecer classificação mais adequada dos acontecimentos que produzem efeitos jurídicos. Assim, os fatos jurídicos em sentido estrito são acontecimentos que criam, modificam, extinguem ou conservam direitos, independentemente da vontade humana. Já os demais, exigem participação volitiva, diferenciando-se os dois primeiros (negócio jurídico e ato jurídico lícito), por estarem conformes ao direito. Os atos ilícitos, que não perdem a qualidade de jurídicos porquanto também provocam a produção de efeitos jurídicos, são, ao contrário, desobedecedores do Direito. Caracterizam-se, estes, também, pelo fato de que as consequências jurídicas deles resultantes operam-se independente da vontade do agente. $\mathrm{O}$ ato é de vontade; os efeitos independem do querer de quem os praticou.

Os negócios jurídicos e os atos lícitos exigem a presença de elementos, necessários à sua validade, conforme é expresso o art. 104 do Código Civil. Não fora isso, há que se lembrar que a vontade é elemento essencial dos atos jurídicos em geral, aqui incluídos os atos lícitos, os ilícitos e os negócios jurídicos.

Maculada à vontade, nos atos jurídicos obedientes à lei, é possível obter-se sua invalidade, por vícios que, em geral, atuam contra a liberdade ou contra a consciência.

Para que algo tenha valor, é preciso que exista. Não tem sentido falar em validade ou em invalidade a respeito do que não existe. A questão da existência é questão prévia. Somente depois de confirmar que algo existe é possível pensar em validade ou em invalidade. Quando não há ato jurídico, nada há que se possa ser válido ou inválido. Os conceitos de validade ou de invalidade se referem, unicamente, a atos jurídicos, isto é, a atos humanos que entraram no mundo jurídico e se tornaram, assim, atos jurídicos.

Os atos jurídicos, inclusive os fatos jurídicos, podem existir sem serem eficazes. O testamento, antes da morte do testador, nenhuma outra eficácia tem que a de negócio jurídico unilateral, que, perfeito, aguarda o momento da eficácia. Há fatos jurídicos que são ineficazes, sem que a respeito deles se possa discutir validade ou invalidade. E, de regra, os atos jurídicos nulos são ineficazes; mas, ainda aí, pode a lei dar efeitos ao nulo, escreveu Miranda (2000, p. 35-39).

Entre os vícios do consentimento tratados pelo Código Civil a partir do art. 138 está a fraude contra credores. Diferencia-se ela pelo fato de, na verdade, não haver 
vício de vontade, de consentimento, mas manifestação volitiva que se qualifica em um fim ilícito. Outros atos são apontados por Antonio Junqueira de Azevedo como portadores da mesma característica, como a lesão enorme e a simulação, embora esta esteja atualmente com solução de invalidação diversa da prevista para a fraude contra credores. ${ }^{2}$

A sistemática de classificação da fraude como ato não válido não é uniforme. Há quem a inclua entre os atos ilícitos. Em geral costuma-se dizer que o ato ilícito se caracteriza como uma infração a um dever jurídico previamente existente. No ato inválido, ao contrário, não haveria tal dever. O ato praticado é faculdade do agente. Se este resolve realizá-lo, porém, deve obedecer aos ditames legais, sob pena de vê-lo invalidado. Exemplo disso é a emancipação. Não precisa o pai emancipar o filho. Se o fizer, porém, deve fazê-lo obedecendo às formalidades legais.

Poder-se-ia dizer que na fraude não há dever jurídico preexistente, embora seja possível ver esse dever na garantia que dá o devedor a seu credor de manter seus bens em seu patrimônio. Há ilícito, aparentemente, ao menos contratual, por infração de implícita obrigação do devedor de manter a garantia dada.

Outra característica do ato ilícito civil é a sua atipicidade. Embora os limites da fraude sejam mais estreitos, especialmente na fraude contra credores, não se pode negar que guarde abrangência de casos suficiente para também ser considerada não típica.

O Código Civil, entretanto, tratou a fraude contra credores - e, também, a fraude à lei - como atos inválidos, a despeito do fim ilícito que ostentam. E assim será ela tratada, a despeito de também se pretender qualificá-la como abuso de direito e, como tal, um ato ilícito. Como ilícito parece entendê-la Silvio de Salvo Venosa, dentro da ideia de que a fraude é o mais grave ato ilícito, pois destrói relações sociais, é responsável por danos de grande vulto que, em geral, são de difícil reparação.

A fraude contra credores tem sido conceituada como o artifício malicioso pelo qual um devedor insolvente faz um contrato verdadeiro para prejudicar seu credor.

Segundo Monteiro (1991, p. 215-223), Laurent escreveu que seria muita pretensão definir, a priori, os caracteres da fraude, tendo em vista que o juiz, com um pouco de bom senso, poderia discutir o assunto em melhores condições que o mais sutil jurisconsulto. Entretanto, num sentido amplo, pode ser conceituada como o artifício malicioso empregado para prejudicar a terceiros.

Mesmo assim, continua Monteiro, a fraude pode ser discutida no âmbito de dois elementos, um objetivo e outro subjetivo.

O elemento objetivo, vinculado a ideia do eventus damni, é um ato totalmente "prejudicial ao credor, por tornar o devedor insolvente, ou por ter sido praticado em estado

A simulação, no Código Civil de 2002, veio tratada como causa de nulidade, enquanto os outros defeitos são considerados causa de anulação. No Código de 1916 a simulação também era causa de anulação. 
de insolvência. No primeiro caso, entre o ato do devedor e a insolvência deste, deve estar entremeado, evidente, o nexo causal, a relação de causa e efeito".

O elemento subjetivo, vinculado ao conceito em latim consilium fraudis, é a "má-fé, o intuito malicioso de prejudicar. Pode advir do devedor, isoladamente, como na renúncia de herança, ou do devedor aliado a terceiro, como na venda fraudulenta".

$\mathrm{Na}$ conceituação de consilium fraudis não tem relevância o animus nocendi, ou seja, a intenção deliberada de prejudicar credores. Basta que o devedor tenha consciência de que, do seu ato, advirão prejuízos. Por isso que a fraude, em certo sentido, pode existir sem ser premeditada (fraus non in consilio, sed in eventu).

Igualmente, em relação ao cúmplice do fraudador (particeps fraudis), não há a necessidade da intenção de prejudicar, bastando o conhecimento que ele tenha, ou deveria ter, do estado de insolvência do devedor e das consequências que, do ato lesivo, resultarão para os credores.

Portanto, escreve, houve apreciável simplificação na teoria da fraude contra credores. Lá, o Direito Romano só concedia ação pauliana, ou revocatória, quando se comprovasse concorrentemente a intenção de prejudicar. Aqui, o Direito brasileiro contenta-se com o eventus domni; ou seja, não exige que o ato seja intrinsecamente fraudulento. Ou melhor, uma vez demonstrados referidos pressupostos, presume-se a fraude.

Segundo Mello (2009, p. 2.005), a fraude contra credores constitui "todo ato de disposição e oneração de bens, créditos e direitos, a título gratuito ou oneroso, praticado por devedor insolvente, ou por ele tornado insolvente, que acarrete redução de seu patrimônio, em prejuízo de credor preexistente".

Monteiro (1991, p. 216-217), citando José Augusto César, entende ser errôneo o título "fraude contra credores", por não corresponder, em verdade, à instituição.

Nesse contexto, a fraude contra credores é um instituto ligado à garantia que o devedor dá ao credor de que a obrigação será adimplida ou reparada. Garantia esta que está presente no momento da celebração da avença, mas que deve perdurar até extinção total da obrigação.

Como se viu, a fraude contra credores não está ligada a um vício de consentimento. $\mathrm{O}$ ato praticado é psicologicamente perfeito. A vontade foi manifestada de forma livre e consciente, mas colorida num fim ilícito, um intuito imoral.

Aponta-se como elementos caracterizadores da fraude contra credores a existência de divida anterior ao ato de alienação. E que essa alienação traga ou agrave a insolvência do devedor. E em geral que esse ato de desfalque patrimonial seja decorrente de um acordo fraudulento, de um acerto para prejudicar. 
A anterioridade da dívida tem fácil explicação. Quando alguém contrata, em geral o faz sabedor de que o patrimônio do devedor garante seu direito, isto é, o cumprimento da obrigação. Não quer o credor perder sua garantia.

Mas não tem o credor legitimidade para contestar ato de disposição patrimonial anteriormente acontecido. Se quando contratou, o devedor já não tinha mais o bem, por certo não se contou com ele para garantir adimplemento da obrigação.

$\mathrm{O}$ ato de disposição patrimonial, porém, deve provocar ou agravar a insolvência do devedor. Insolvência é situação em que o ativo é menor que o passivo.

Segundo Diaz (1993, p. 58-70), Humberto Theodoro Júnior distingue a insolvência, que é a impossibilidade de solver, no momento, uma obrigação, seja qual for o motivo, da insolvabilidade, que é a ausência de meios para solver as dívidas, oriunda de ser o ativo do devedor menor do que seu passivo. A primeira pode ser ocasional e passageira. A segunda é crônica ou definitiva.

O código foi abrangente na indicação do ato que venha a causar a insolvência: alienações, como venda, doação, troca, dação em pagamento, renúncia de direito, perdão, privilégio em pagamento, entrega de garantia real, entre outras, são exemplos de atos em fraude contra credores.

Embora a redação do Código pareça abranger toda e qualquer espécie de diminuição patrimonial, por certo há aquelas que não podem ser desfeitas. É impossível voltar atrás. É que ocorre, por exemplo, no caso de o devedor destruir o seu carro, único bem que garantia seus credores.

A fraude contra credores se tipifica quando o devedor pratica ato que reduz seu patrimônio. Não há fraude, por isso, quando ela não aproveita oportunidade para aumentá-lo.

Não há fraude, por isso, na não aceitação de doação.

Situação fática semelhante opera-se no direito das sucessões. O herdeiro devedor que não aceita a herança também não desfalca seu patrimônio, apenas deixa de o aumentar. Aqui, entretanto, há dispositivo específico tornando ineficaz o ato. Estabelece o art. 1813 do Código Civil que "quando o herdeiro prejudicar os seus credores, renunciando à herança, poderão eles, com autorização do juiz, aceitá-la em nome do renunciante".

$\mathrm{O}$ artigo permite controvérsia em relação ao legado. Monteiro e Venosa (1991, p. 223-293) defendem que a aceitação pelos credores está limitada à herança. Esta seria praticamente um “direito adquirido". Com ela é bem provável que tenha contado o credor. Pode este ter feito o contrato na expectativa de que os bens, não os atuais do devedor, mas aqueles que ele está prestes a herdar, garantam seu direito. Depois, é incomum renunciar à herança. Se isso acontece, pode o legislador presumir instituto desviado da boa-fé. 
Relativamente ao legado, dizem os autores citados, pode haver motivos para a não aceitação.

Alvino Lima tem posição divergente, e parece com razão. Também o legado não é comum deixar de ter aceitação. Mas se motivos relevantes apontam para a necessidade de ato nesse sentido, que sejam apontados pelo sucessor. É preciso, porém, que o motivo seja expresso, sob pena de não poder ser investigado (art. 140 do Código Civil).

Também não pode ser considerado em fraude contra credores a desistência de direitos pessoais. A emancipação do filho menor não garante reconhecimento de que a perda consequente do usufruto legal sobre os bens do emancipado foi em fraude contra credores. Já se reconheceu, entretanto, que a autorização do marido para a mulher renunciar a legado de usufruto caracterizou-se como fraude contra credores.

Houve um processo ${ }^{3}$ onde se pretendia o reconhecimento de fraude em testamento onde o pai deixava todo seu patrimônio para o filho insolvente com cláusula de impenhorabilidade. Entendeu-se que o ato era de terceiro e, por isso, não poderia ser tido como em fraude contra credores. Talvez hoje a solução pudesse ser, ao menos em parte, diversa, isso em razão do art. 1.848 do Código Civil, que proíbe clausulação da legítima imotivadamente. Seria, então, possível ver fraude aos credores a inércia do herdeiro em não buscar o afastamento da impenhorabilidade incidente sobre sua legítima.

A fraude contra credores pode acontecer por via de atos gratuitos ou de atos onerosos.

Nos primeiros, contentou-se a lei com a presença do requisito objetivo, o evento danoso.

A solução legal é de fácil explicação. Manter o bem com o terceiro beneficiado é garantir vantagem, mas, ao mesmo tempo, essa solução causa prejuízo aos credores. A invalidação do ato, por sua vez, impede o prejuízo ao credor. Mas não causa dano ao beneficiado, apenas evita que tenha ele benefício. Entre criar vantagem e provocar prejuízo ou evitar prejuízo sem trazer dano, o legislador optou por esta última solução.

É bom lembrar que o devedor não pode desconhecer sua situação econômica. E se ela é aflitiva, não parece apto a distribuir benemerências. Se assim age, presume-se estar de má-fé. E, se de um lado, quem está insolvente não realiza liberalidades, de outro a ninguém é lícito locupletar-se à custa alheia, o que ocorreria com o terceiro adquirente em relação ao credor se fosse o protegido.

Algumas questões podem ser levantadas. Primeiro, só o credor quirografário pode invocar a proteção do instituto. Melhor seria dizer que apenas os que têm garantia

O coautor José Luiz Gavião de Almeida atuou no respectivo Processo. 
real em relação ao bem alienado não podem usar da fraude contra credores. Privilegiados podem, pois dependem do bem no patrimônio do devedor, tal qual os credores sem privilégio, para satisfazerem seus direitos. Os credores com garantia real não têm interesse na invalidação da transmissão porque esse ato não os prejudica e podem buscar a garantia com quer que ela esteja. Mas não se pode impedir o credor com garantia real de usar a proteção da fraude contra credores em relação a outras alienações, e para garantia do crédito que exceder ao direito real que tem.

Quando o ato de alienação é oneroso a aplicação da fraude à execução fica mais complexa. Agora se exige não apenas o evento danoso, mas também o acordo fraudulento. Esse elemento, subjetivo, indica a má fé do devedor e seu parceiro, o terceiro adquirente, que praticaram ato sabendo-o prejudicial ao credor.

Também a explicação não é difícil. Se no primeiro caso a solução estava em causar dano ao credor com benefício ao adquirente ou, sem prejuízo a este evitar o dano ao credor, aqui, as duas situações (ficar o bem ou com o credor ou com o terceiro adquirente), sempre vai provocar prejuízo a alguém. Por isso é melhor que, estando o adquirente de boa-fé, seja ele, em homenagem a essa boa-fé, o protegido. E essa boa-fé é, hoje, medida pelas providências que tomou para verificar a lisura do negócio, ou seja, a inexistência de elementos que indicassem haver a fraude contra credores.

Jorge Americano (1932) escreveu sobre a importância da boa-fé, segundo discurso de Silvio Rodrigues, em homenagem póstuma (1969):

Fala-se tanto em princípios gerais de direito que vivo a procurá-los e acho que em toda minha vida só encontrei dois que realmente se revestissem do indispensável caráter de generalidade. $\mathrm{O}$ princípio do repúdio à violência e o princípio do respeito a boa-fé. Respeitados esses dois princípios, pode-se estruturar todo um sistema jurídico.

Não se dispensa aqui a causação ou agravamento da insolvência, isto é, a presença do elemento objetivo, o evento danoso. Há que se lembrar, porém, que para ser considerado como tal, o ato de alienação patrimonial deve ser a causa direta da insolvência. Isto é, se o ato tido por fraudulento causar indiretamente a insolvência, não pode ele ser invalidado. Por exemplo: os mais antigos por certo lembram da história do Tio Patinhas e de sua moeda número um, a qual lhe trazia sorte. A venda dela, quando os cofres do Tio Patinhas ainda estão abarrotados de dinheiro, por certo não caracteriza fraude contra credores, embora todos saibam que essa venda levará o vendedor, mais tarde, à bancarrota.

O crédito a termo ou condicional não inibe a utilização da fraude contra credores. Aquele a termo já está adquirido. O condicional, embora haja discussão sobre já estar adquirido ou não, também garante a invocação do instituto. Como justificou Jean 
Charles Florent Demolombe, em seu Cours de Code Civil, se o devedor não aguardou o implemento da condição para fraudar, não precisa o credor aguardá-la para invalidar o ato fraudulento.

Na hipótese de sub-rogação de crédito, mesmo que se dê depois do ato de alienação fraudulenta, não está a invalidação obstada. A sub-rogação traz novo credor, embora a dívida seja antiga.

Mesma solução não pode ser dada na hipótese de novação da dívida.

Voltando ao elemento subjetivo, traz ele a impressão de que haveria de se provar que o devedor e o terceiro adquirente travaram acordo para prejudicar o credor. Tal requisito, se fosse exigido, seria de impossível comprovação. Por isso, o consilium fraudis vem ganhando perfil diverso. Há, inicialmente, que analisar separadamente a participação dos atores desse negócio fraudulento.

Entende-se presente o elemento subjetivo, para o devedor, desde que com sua atuação instaure-se sua insolvência, ou ela se agrave. O Código Civil de 1916 tinha tratamento diverso. Comprovado que o devedor não tinha ciência de que com seu ato caiu em insolvência, não se reconhecia o elemento subjetivo, mesmo que o ato tido por fraudulento fosse gratuito. ${ }^{4}$ Hoje, como se viu, o elemento subjetivo é sempre presumido nos atos gratuitos. $\mathrm{O}$ art. 158 do Código Civil o pressupõe mesmo que o devedor ignore que, com seu ato, cairá em insolvência. ${ }^{5}$

Nos atos onerosos, porém, embora haja presunção do elemento subjetivo para o devedor que cai em insolvência, se ficar comprovado que ele, devedor, desconhecia essa situação, faltará o elemento subjetivo para a caracterização da fraude.

Se a má-fé do devedor é presumida, a do terceiro adquirente não pode ser. $\mathrm{E}$ aqui a escolha do legislador, entre duas soluções, é mais difícil. Invalidar o ato prejudica o terceiro adquirente, que teve contraprestação no ato que se invalidou. Por exemplo, ficará ele privado do preço se tiver que devolver o objeto comprado.

Entre prejudicar o credor ou o terceiro adquirente, em homenagem à boafé desse terceiro o ato fica mantido e a fraude não é reconhecida. A solução apresenta vantagem, ainda, ao garantir a segurança jurídica. E se sustenta, outrossim, no fato de que o credor, podendo tomar medidas para garantir seu crédito, nada fez. Pune-se, então, a desídia.

$4 \quad$ Art. 106. Os atos de transmissão gratuita de bens, ou remissão de dívida, quando os pratique o devedor já insolvente, ou por eles reduzido à insolvência, poderão ser anulados pelos credores quirografários como lesivos dos seus direitos (art. 109).

5 Os negócios de transmissão gratuita de bens, ou remissão de dívida, se os praticar o devedor já insolvente, ou por eles reduzido à insolvência, ainda quando o ignore, poderão ser anulados pelos credores quirografários como lesivos dos seus direitos. 
Mas apenas se protege o terceiro adquirente se estava ele de boa-fé. Provado que estava de má-fé a ele são carreados os prejuízos do ato irregular do devedor.

A má-fé do terceiro tem sido reconhecida quando se comprova que ele tinha ciência da situação econômica precária do devedor. Isso se dá, por exemplo, quando a insolvência do devedor é notória. Não se há de confundir notoriedade com "a voz do povo", embora esta sirva como prova desse fato. Assim também quando circunstância de proximidade dos contratantes impunham o conhecimento da insolvência. Ou quando o adquirente não tomou as cautelas de praxe exigidas na normalidade dos negócios de igual natureza. Por exemplo, tem sido entendido desidioso o adquirente de bem imóvel que não busca tirar certidões negativas de distribuidores cíveis e do Cartório de Protestos, do vendedor. Se essa falta de diligência serviu para esconder a insolvência do devedor, mostra falta de cautela do adquirente, que passa a ter má-fé reconhecida; e por consequência, completa o elemento subjetivo justificador da tipificação da fraude contra credores.

Questão interessante e que tem sido objeto de invocação nos processos em que se buscam o reconhecimento da fraude contra credores é a alegação no sentido de que o ato anulado não trouxe insolvência quando praticado. O patrimônio do devedor, por exemplo, não teria ficado prejudicado com a venda acusada de fraudulenta, pois teria ocorrido simples substituição de um bem, por exemplo uma casa, por dinheiro, no valor correspondente.

A fraude se caracteriza não pela simples e momentânea substituição do bem cujo valor garantia o credor, mas pela intenção de que, com essa substituição, se consiga acabar ou apenas esconder a nova garantia. Por isso que Jorge Americano, ao tratar do assunto em Acção Pauliana (1932), diz que a alienação que se busca invalidar é meio de converter os bens imóveis ou móveis de difícil ocultação, em moeda corrente, facilmente ocultável.

Efetivamente, se a venda se faz e o dinheiro é penhorado, não há razão para a invalidação da alienação. Outro não poderia ser o entendimento face ao disposto no art. 160 do Código Civil: "se o adquirente dos bens do devedor insolvente ainda não tiver pago o preço e este for, aproximadamente, o corrente, desobrigar-se-á depositando-o em juízo, com a citação de todos os interessados". Igual solução se o preço for pago e penhorado.

A fraude contra credores não se confunde com a simulação. Esta é ato falso, mentiroso, inexistente. A fraude pressupõe ato verdadeiro. Como observa Alvino Lima, a fraude decorre sempre de prática de atos legais em si mesmos, mas com finalidade ilícita de prejudicar terceiros, ou, pelo menos, frustrar a aplicação de determinada regra jurídica.

A fraude contra credores não se confunde com o dolo. Neste um dos partícipes do ato busca prejudicar o outro. O vício que macula o ato é a falta de consciência 
da manifestação de vontade do enganado. Na fraude contra credores são os dois partícipes buscando enganar e prejudicar terceiro.

\title{
4. Ação Pauliana
}

A ação pauliana tem origem incerta e nebulosa para muitos, mas, com destaque, tem sido atribuída ao Direito Romano. A origem parece lógica. Foi criada para "complementar as competências" do Pretor, com o objetivo de coibir os atos praticados pelo devedor, fraudatórios da garantia patrimonial dos credores. A responsabilidade, inicialmente, atingia o corpo do devedor. Posteriormente, passou a incidir sobre o patrimônio do devedor, que poderia dilapidá-lo por meio de doações ou outros meios. Foi necessário, por isso, a criação de mecanismos que garantisse o retorno do bem ao patrimônio do devedor. A ação pauliana propiciava, portanto, a revocação (de revocar, chamar para trás) da transmissão. Posteriormente, foi inserindo-se na generalidade das legislações.

No mesmo sentido a súmula de Gaius Marius (157 a.C. - 86 a.C.). É interessante para compreender o contexto da ação pauliana na época:

\begin{abstract}
A princípio, tinha caráter penal, e era dirigida contra o terceiro que se houvesse prestado às manobras fraudulentas do devedor. Depois, veio a ser contra o donatário que tivesse tirado proveito do delito cometido pelo devedor. No início, o réu era condenado a uma pena pecuniária, cuja execução não se cumpriria se o bem, indevidamente desviado, fosse restituído ao patrimônio do devedor. Posteriormente, não obstante a sua natureza pessoal, a ação pauliana apresentouse como uma actio in rem, tendo por objeto a nulidade do ato fraudulento e a recuperação da coisa para o patrimônio do devedor.
\end{abstract}

Cahali (2013, p. 83-95) também registra esta história jurídico-romana.

A desconstituição do ato praticado em fraude contra credores é feita pela via da ação revocatória ou ação pauliana. Mas é possível o desfazimento por outra via. Quando o ato prejudicial é o de renúncia da herança, sua ineficácia se obtém com o ato de aceitação pelos credores, que se dá nos autos do inventário. Quando o ato prejudicial é uma renúncia à prescrição, ela pode ser afastada pela alegação feita pelos credores no processo movido ao devedor. Assim deve-se interpretar e aplicar o que está previsto no art. 193 combinado com o art. 203, ambos do Código Civil.

Por isso não se confundem as ações revocatórias com aquelas que servem à invalidação da simulação. A revocatória busca desfazer (ou tornar ineficaz para o credor) uma alienação verdadeira. A ação de simulação busca o reconhecimento de situação 
aparente, mentirosa, não verdadeira. A ação pauliana busca rescindir o ato fraudulento. A ação de simulação é declaratória.

A ação revocatória deve ser promovida pelos credores a quem aproveite. A declaratória de simulação pode ser ajuizada pelo Ministério Público, ou até pelas partes, se inocente (a questão agora ficou questionável em razão de haver o Código excluído a simulação inocente). Nas ações revocatórias é preciso comprovar insolvência. $\mathrm{Na}$ declaratória de simulação, não. A ação pauliana afeta o ato até o proveito do credor. A ação de simulação atinge todo o ato mentiroso. A ação pauliana é necessária para a invalidação do ato (salvo os exemplos dados). A ação de simulação não é obrigatória, pois a invalidação pode ser reconhecida de ofício.

Espínola (1929, p. 570-596) escreve, todavia, que as ações possam ser cumuladas. Na verdade, não é rara a hipótese em que há dúvida sobre ser o ato invalidando verdadeiro ou falso, embora fique patente que ele se deu para prejudicar credores.

Ele também escreve que a ação pauliana é inquestionavelmente uma ação de anulação; destina-se a revogar o ato lesivo aos interesses dos credores; tem por efeito restituir ao patrimônio do devedor insolvente o bem subtraído, para que sobre o acervo assim integralizado recaia a ação dos credores para que obtenham a satisfação de seus créditos.

No contexto do Código Civil de 1916, Americano (1932, p. 75-101) escreve que, efetivamente, o ato é anulável, e, pronunciada a sentença, a reversão ao acervo do devedor dos bens objeto da pauliana deve aproveitar a todos os credores, tanto os que promoveram a ação quanto os que não o fizeram, quer os anteriores quer os posteriores ao ato lesivo.

A fraude contra credores também não se confunde com a fraude à execução, está prevista e regulada pelo Código de Processo Civil. Tem havido, porém, uma tendência de aproximá-las. Das hipóteses justificadoras do reconhecimento da fraude à execução, previstas no art. 792 do CPC (antigo 593 do CPC/73), somente se entende possível reconhecê-la quando o bem alienado já estiver penhorado e a penhora inscrita no registro de imóveis, conforme Súmula 375 do Superior Tribunal de Justiça.

Cahali (2013, p. 61) relembra, com base na Súmula 375 do STJ, que “embora os menos avisados se deslumbrem na demonstração do óbvio, isto é, de que trata de institutos de características inconfundíveis, mostra-se incontestável que, ontológica e historicamente, a fraude à execução representa um aspecto da fraude contra credores".

Monteiro (1991, p. 223) buscou distinguir a fraude à execução da fraude contra credores. Escreve que a fraude de execução é incidente do processo, regulado pelo direito público; fraude contra credores é defeito dos atos jurídicos, disciplinado pelo direito privado. A primeira pressupõe demanda em andamento, sendo levada a efeito pelo devedor para lhe frustrar a execução; o reconhecimento da segunda não está subordinado 
à preexistência de demanda em relação ao ato considerado fraudulento. Aquela torna nulo o ato, ao passo que esta, apenas anulável. A decretação da fraude de execução independe de revocatória. Os bens do executado continuam a responder pelas dívidas deste, como se nunca tivessem saído de seu patrimônio. No tocante ao reconhecimento da fraude contra credores, o reconhecimento dela depende do ajuizamento da ação revocatória. A fraude contra credores, uma vez reconhecida, aproveita a todos os credores. A fraude de execução, ao contrário, aproveita apenas ao exequente. Nela, o vício é mais patente, muito mais visível, havendo até quem afirme se tratar de presunção juris et de jure a verificação de qualquer dos fatos apontados pela lei como caracterizadores dela.

Há consenso na doutrina brasileira de que a fraude à execução é instituto processual, enquanto a fraude contra credores se integra no direito material. Se, na fraude à execução há violação da função processual executiva por molestar interesses de ordem pública; a fraude contra credores apresenta-se como defeito dos atos jurídicos, implicando na lesão de interesses privados.

Conforme Jurisprudência do Tribunal de Justiça de São Paulo (TJSP), segundo o AC 21.014-1, da $3^{\mathrm{a}}$. CC, a ação pauliana está submetida ao Direito Civil, ao passo que a fraude à execução está disciplinada no Direito Processual Civil. Apesar deste Acórdão ser anterior a promulgação do Código Civil de 2002 e do Código de Processo Civil de 2015, os princípios que fundamentam a ação pauliana e a fraude à execução são equivalentes.

Amílcar de Castro, citado por Cahali (2013, p. 71), salienta que "todos os conflitos de interesses particulares oriundos da fraude contra credores resolvem-se pelas regras do Direito Privado; ao passo que os que se original da fraude à execução compõemse todos pelas normas de Direito Processual (substancial) por estar em jogo o sacrifício de um interesse público, que é o que tem o Estado de fazer justiça”.

A fraude a credores, uma vez reconhecida produz, como se disse, o retorno do bem que garantia a credores, ao patrimônio do devedor. Mas não aproveita apenas ao devedor que demandou a invalidade, mas a todos os credores (art. 165 do Código Civil).

Theodoro Júnior (2002, p. 55), citando Clóvis Bevilaqua, escreve que a reação da ordem jurídica contra o ato nulo não acontece sempre com a mesma intensidade. Isto porque os interesses feridos pela ilegalidade nem sempre são da mesma natureza ou da mesma relevância.

Assim, quando a norma violada é daquelas que agasalham princípios básicos da ordem jurídica, pondo em jogo interesses de ordem pública, ocorre a nulidade de pleno direito, como a reação mais enérgica contra a prática ilegal. Mas quando os preceitos ofendidos pelo ato se destinam mais particularmente a proteger os interesses privados da pessoa que dele participou, a reação contra sua eficácia 
é atenuada porque dependerá da vontade individual do interessado. $\mathrm{O}$ ato, neste caso, será apenas anulável.

Segundo Diaz (1993, p. 58-70), citando o Código Civil italiano (art. 2.740), "IL debitore responde del l'adempimento dele obbligazioni con tutti i suoi beni presenti e futuri", ou seja, o devedor é responsável pelo cumprimento das obrigações com todos os seus ativos, presentes e futuros. Assim, o devedor tem a obrigação de não prejudicar a garantia dada aos credores. A responsabilidade patrimonial gera o dever de considerar bens suficientes para tutelar o direito dos credores. Trata-se de um limite imposto ao devedor no poder de disposição de seus bens.

Esse dever, continua Diaz, corresponde a um direito por parte do credor: efetivar a obrigação nos bens do devedor. Em consequência, se por algum fato do devedor isso não for possível, o direito lhe concede um meio para atacar esse ato: a ação pauliana, que resulta, desse modo, a via eficaz para o combate à fraude contra credores.

Portanto, a fraude pauliana se apresenta quando um devedor insolvente, ou na iminência de torna-se insolvente, consuma atos suscetíveis para diminuir seu patrimônio, reduzindo, desse modo, a garantia que representa para a cobrança de suas dívidas.

Segundo Lima (1965, p. 159-160), a ação revocatória ou pauliana é concedida somente contra os atos pelos quais o devedor se empobrece, isto é, atingindo a garantia patrimonial de seus credores e não aqueles atos com os quais se recusa a enriquecer, ou se negligencia a aumentar o seu patrimônio.

No Código Civil de 1916 havia discussões e preocupação da doutrina em criar critérios de diferenciação entre prescrição e decadência, tendo em vista estarem previstos no mesmo dispositivo. Atualmente, os efeitos das discussões e do parecer da época já estão "contemplados" pelo Código Civil de 2002. Isso porque, segundo os arts. 205 e 206, há “vários prazos” de prescrição, a depender da natureza jurídica, enquanto a decadência está regulada nos "outros prazos".

Conforme precedentes da $1^{\mathrm{a}}, 3^{\mathrm{a}}$ e $4^{\mathrm{a}}$ turmas e da $2^{\mathrm{a}}$ Seção do Superior Tribunal de Justiça (STJ), REsp. 46.192-2-SP, a fraude deve ser discutida em ação pauliana, e não em embargos de terceiros.

Discute-se, outrossim, se nos embargos de terceiro onde se busca desconstituir o reconhecimento de invalidade por fraude contra credores pode-se reconhecer a fraude à execução. Dinamarco (1971, p. 17-30), citando Francesco Carnelutti, entende ser possível; portanto, a favor. É uma de suas teses apresentada no III Colóquio de Direito Processual Civil. O Superior Tribunal de Justiça (STJ) entende ser impossível; portanto, contra. 


\section{Conclusões}

As nuances conceituais e doutrinárias sobre a fraude contra credores, analisadas neste trabalho, demonstram a sua importância tanto no âmbito do Direito Material como no âmbito do Direito Processual, desde os tempos primitivos até os dias contemporâneos. É um instituto muito importante para garantir, efetivar e preservar direitos de credores e exequentes. Obviamente que tais direitos não podem sobrepor sumariamente os direitos constitucionais dos devedores e executados de ter ampla defesa, de requerer o contraditório e de ter a presunção de inocência até o trânsito em julgado.

A fraude contra credores encontra maior complexidade de identificação em qual âmbito de conduta: insolvência notória ou insolvência presumida? Se a resposta é difícil, segundo Laurent, Monteiro (1991, p. 215-223) faz as seguintes observações: contratos onerosos são anuláveis desde que notória a contemporânea insolvência do devedor, ou desde que haja motivo para ser conhecida da outra parte. A insolvência pode ser, portanto, notória ou presumida.

É insolvência notória quando conhecida por todos, quando é pública, manifesta, do conhecimento geral, mercê de protestos, quando é publicada pela imprensa ou quando há cobrança contra o devedor. É insolvência presumida quando o adquirente tinha motivos para saber do precário estado financeiro do alienante.

No âmbito de conhecimento presumido, prevalece na jurisprudência a seguinte orientação: a) o parentesco próximo, ou afinidade próxima, entre os contratantes, é indício de fraude, dentro da ideia fraus inter parentes facile praesumitur. Assim, pai que contrata com filho insolvente dificilmente poderá arguir sua ignorância sobre a má situação econômica do filho, ou seja, a scientia se presume tanto em casos como este como noutros casos análogos; b) também não pode alegar ignorância desse estado quem, anteriormente, havia feito protestar títulos de responsabilidade do devedor; c) relações íntimas de amizade, convivência frequente, negócios mútuos ou comuns, levam a presumir ciência do adquirente quanto à má situação patrimonial do devedor e impossibilidade de solver suas obrigações; d) emprego de cautelas excessivas é, também, quase sempre, indicativo de fraude. Quem contrata com devedor insolvente evidencia intuito malicioso, pois um contratante de boa-fé instintivamente se retrai quando percebe o real status econômico do devedor-interessado. Caracteriza-se assim a participatio fraudis.

Diaz (1993, p. 58-70), citando Jorge Americano, escreve que a prescrição da ação pauliana na tradição romana era de um ano útil. No Brasil, o Código Civil de 2016 tratou como sendo de quatro anos (art. 178, § 9, inciso V, alínea $b$ ). Em discussões no Congresso brasileiro, Manuel Antônio Duarte de Azevedo propôs uma redução do prazo prescricional. A proposta foi rejeitada em parecer da Faculdade Livre de Direito do Estado do Rio de Janeiro, que afirmava: 
Reduzir a um ano o prazo da prescrição da ação dos credores para revogarem os actos practicados pelo devedor em fraude de execução é em absoluto inaceitável. Ante a relaxação dos costumes actuaes, já são por demais escassos os recursos das víctimas das fraudes. Por que ainda mais afligi-los com a diminuição do prazo?

Talvez por isso que Ivair Nogueira Itagiba escreveu: "o Direito não tolera a fraude, tampouco já teve indulgência para com a má-fé. Os ditames éticos procuram expulsá-las de todos os departamentos do Direito".

Para todos os tipos de fraudes, inclusive a fraude contra credores, seja notória ou presumida, seja entre terceiros ou entre parentes, Marcus Tullius Cicero (10643 a.C.) articulou uma interessante conceituação de direitos e deveres:

Embora o erro possa ser feito de duas maneiras, isto é, pela força ou pela fraude, ambas são bestiais; a fraude parece pertencer à raposa astuta, enquanto a força pertence ao leão. Apesar de ambas serem totalmente indignas do homem, a fraude é a mais desprezível. Isso porque, de todas as formas de injustiça, nenhuma é mais flagrante que a do hipócrita que, no exato momento em que é falso, faz questão de parecer virtuoso. ${ }^{6}$

São Paulo, 28 de julho de 2020.

\section{Referências}

AMERICANO, Jorge. Da accao pauliana. 2. ed. São Paulo: Livraria Acadêmica, 1932.

BOUZON, Emanuel. O código de Hammurabi. 8. ed. Petrópolis: Vozes, 2000.

CAHALI, Yussef Said. Fraude contra credores. 3. ed. revista e atualizada. São Paulo: Revista dos Tribunais, 2013.

CASTRO, Amílcar. Comentários ao código de processo civil. São Paulo: Revista dos Tribunais, 1974. v. 8.

CICERO, Marcus Tullius. De Officiis. English translation by Walter Miller. London: William Heinemann; New York: The MacMillan Co, 1913.

6 Cicero (1913, p. 45-46). "While wrong may be done, then, in either of two ways, that is, by force or by fraud, both are bestial: fraud seems to belong to the cunning fox, force to the lion; both are wholly unworthy of man, but fraud is the more contemptible. But of all forms of injustice, none is more flagrant than that of the hypocrite who, at the very moment when he is most false, makes it his business to appear virtuous". 
CRETELLA JÚNIOR, José. Curso de direito romano: o direito romano e o direito civil brasileiro. 23. ed. Rio de Janeiro: Forense, 2000.

DIAZ, Júlio Alberto. A fraude contra credores: uma visão comparada. Revista de Doutrina e Jurisprudência, Brasília, v. 41, p. 58-72, jan./abr. 1993.

DINAMARCO, Cândido Rangel. A execução provisória na teoria dos efeitos dos recursos. Revista Justitia, São Paulo, n. 74, p. 17-31, 1971.

DINAMARCO, Cândido Rangel. Vocabulário de direito processual. Revista Justitia, São Paulo, v. 42, n. 109, p. 188-200, mar./jun. 1980.

DONINI, Ambrogio. Breve história das religiões. Rio de Janeiro: Civilização Brasileira, 1965.

ESPÍNOLA, Eduardo. Manual do codigo civil brasileiro. Rio de Janeiro: Jacintho Ribeiro dos Santos, 1929. v. 3.

GILISSEN, John. Introdução histórica ao direito. Trad. de A. M. Hespanha e L. M. Macaísta Malheiros. 3. ed. Lisboa: Fundação Calouste Gulbenkian, 2001.

GONZALEZ, Everaldo Tadeu Quilici. A filosofia do direito na idade antiga. Rio Claro: Obra Prima, 2005.

GOWER, Ralph. Usos e costumes dos tempos bíblicos. Rio de Janeiro: CPAD, 2002.

GRAU, Eros Roberto. A ordem econômica na Constituição de 1988: interpretação e crítica. São Paulo: Malheiros, 2008.

LIMA, Alvino. A fraude no direito civil. São Paulo: Saraiva, 1965.

MELLO, Marcos Bernardes de. Teoria do fato jurídico: plano da validade. 9. ed. São Paulo: Saraiva, 2009.

MIRANDA, Francisco Cavalcanti Pontes de. Tratado de direito privado. Campinas: Bookseller, 2000. t. 4.

MONTEIRO, Washington de Barros. Curso de direito civil. São Paulo: Saraiva, 1991. v. 3.

PAGE, Henri de. Traité élémentaire de droit civil belge. Bruxelles: E. Bruylant, 1942. v. 3.

PARODI, Lorenzo. Manual das fraudes. 2. ed. Rio de Janeiro: Brasport, 2008.

SANTOS, Carlos Maximiliano Pereira dos. Hermenêutica e aplicação do direito. 18. ed. 5. tir. Rio de Janeiro: Forense, 2000.

SILVA, Oscar José de Plácido e. Vocabulário jurídico. Rio de Janeiro: Forense, 1997. v. 2.

THEODORO JÚNIOR, Humberto. Dos defeitos do negócio jurídico no novo código civil: fraude, estado de perigo e lesão. Revista da EMERJ, Rio de Janeiro, v. 5, n. 20, p. 51-78, 2002.

VENOSA, Sílvio de Salvo. Direito civil. São Paulo: Atlas, 2017. v. 1: parte geral. 
